\title{
PENGARUH MODEL PEMBELAJARAN DIRECT INSTRUCTION DENGAN MEDIA MACROMEDIA FLASH TERHADAP HASIL BELAJAR FISIKA KELAS XI SMAN 1 KOPANG
}

\section{INFLUENCE OF DIRECT INSTRUCTION LEARNING MODEL WITH MACROMEDIA FLASH MEDIA ON PHYSICS LEARNING OUTCOME OF CLASS XI SMAN 1 KOPANG}

\author{
Laili Niswatun Sani, Satutik Rahayu, Hikmawati \\ Program Pendidikan Fisika, Fakultas Keguruan dan Ilmu Pendidikan, Universitas Mataram \\ Jalan Majapahit No. 62, Mataram, 83125, Lombok, Indonesia \\ Email: malamlaily34@gmail.com
}

Diterima: 18 Februari 2018. Disetujui: 20 Maret 2018. Dipublikasikan: 31 Maret 2018

\begin{abstract}
Abstrak. Abstract: Penelitian ini bertujuan untuk mengetahui pengaruh model Direct Instruction dengan simulasi macromedia flash terhadap hasil belajar fisika siswa di SMAN 1 Kopang tahun akademik 2016/2017 tentang impuls dan momentum. Jenis penelitian ini adalah eksperimen dengan desain kelompok kontrol posttest only. Populasi dalam penelitian ini adalah seluruh siswa kelas XI SMAN 1 Kopang dengan jumlah siswa 83 tersebar ke dalam tiga kelas. Sampel penelitian ini adalah XI IPA 2 berjumlah 28 siswa sebagai kelas eksperimen dan XI IPA 1 sebanyak 27 siswa sebagai kelas kontrol yang diambil secara cluster random sampling. Hasil penelitian menunjukkan bahwa rata-rata kelas XI IPA 2 dan XI IPA 1 adalah 70,71 dan 62,04, secara statistik data hasil tes berdistribusi normal dan homogen. Hasil penelitian yang diperoleh adalah analisis dengan $\mathrm{t}$-test polled varians, dan hasilnya menunjukkan $\mathrm{t}_{\text {hitung }}=2,33$ dan $\mathrm{t}_{\text {tabel }}=2,00$ pada tingkat signifikan $5 \%$. Hipotesis nol Ho ditolak karena $t_{\text {hitung }}>t_{\text {tabel }}$, sehingga dapat disimpulkan bahwa model pembelajaran Direct Instruction dengan simulasi macromedia flash berpengaruh terhadap hasil belajar fisika siswa di SMAN 1 Kopang tahun akademik 2016/2017.
\end{abstract}

\begin{abstract}
This research aimed to determine the influence of Direct Instruction model with macromedia flash simulation toward student's physics learning outcomes at SMAN 1 Kopang academic year 2016/2017 in the impulse and momentum topic. This research type was experiment with posttest only control group design. The populations in this research were all students in XI grade SMAN 1 Kopang (83 students). The sampel of this research was XI IPA 2 (28 students) as experiment class and XI IPA 1 (27 students) as control class were taken by cluster random sampling. The results showed that the average grade XI IPA 2 and XI IPA 1 were 70,71 and 62,04 , statistically the test data was normally distributed and homogeneous. The t-test polled varians was applied to obtain the study result. The results showed that $\mathrm{t}_{\text {count }}=2,33$ and $\mathrm{t}_{\text {table }}=2,00$ at significant level of $5 \%$. In conclusion, due to $t_{\text {count }}>t_{\text {table, }}$, the direct instruction teaching model with macromedia flash simulation has influence toward the student's physics learning outcomes at SMAN 1 Kopang academic year 2016/2017.
\end{abstract}

Keyword: direct instruction, macromedia flash, study outcome

\section{PENDAHULUAN}

Salah satu permasalahan yang dihadapi dunia pendidikan saat ini adalah lemahnya proses pembelajaran. Proses pembelajaran hanya menekankan pada kemampuan siswa untuk menjawab soal. Siswa hanya menghafal rumus tanpa mengetahui konsep sebenarnya. Siswa kurang mampu mengaplikasikan konsep-konsep yang dipelajarinya dikehidupan nyata di mana siswa dituntut untuk mampu menghubungkan suatu peristiwa dengan dengan apa yang mereka pelajari di sekolah. Akibatnya, banyak siswa yang merasa bahwa beberapa pelajaran yang disajikan di sekolah sangat sulit karena banyaknya konsep-konsep dan rumus-rumus yang sulit dipahami. Hal menyebabkan kurangnya semangat siswa untuk mendapatkan hasil belajar yang maksimal.

Permasalahan yang sama terjadi pada pembelajaran fisika. Fisika sebagai bagian dari sains mengkaji pengetahuan mengenai gejala-gejala atau fenomena yang terjadi di alam. Fisika berisi kumpulan fakta-fakta, konsep-konsep atau prinsiprinsip tentang fenomena-fenomena alam yang selanjutnya akan diterapkan dalam kehidupan sehari-hari. Hal ini menjadikan fisika sebagai mata pelajaran yang sangat dibutuhkan. Kebutuhan ini berupa kebutuhan manusia untuk memecahkan masalah, di mana manusia merupakan mahluk hidup yang memiliki rasa keingintahuan tinggi. Keingintahuan ini menyebabkan manusia tidak puas dan cenderung merasa bosan jika yang dilakukannya hanya mendengar tanpa melihat sendiri peristiwa sebenarnya. Pembelajaran di sekolah tidak memungkinkan untuk menunjukkan semua peristiwa secara langsung dan nyata, misalnya pada peristiwa tumbukan antara sebuah motor dengan sebuah mobil. Banyak juga konsep-konsep maupun prinsip-prinsip fisika yang bersifat abstrak dan sulit untuk dibayangkan oleh siswa. Oleh karena itu dibutuhkan model pembelajaran dan media pembelajaran yang tepat [1-5]. Model pembelajaran 
yang umum diterapkan dalam pembelajaran fisika di SMAN 1 Kopang adalah model konvensional dengan metode ceramah dan diskusi kelompok. Kegiatan pembelajaran dilakukan berupa diskusi untuk menyelesaikan soal-soal tanpa membahas konsep materi yang dijelaskan.Penggunaan media bantu belajar pun jarang dilakukan. Hal inilah yang menyebabkan siswa kurang berminat mengikuti pembelajaran fisika, sehingga hasil belajar fisika siswa rendah.

Permasalahan di atas dapat diatasi dengan cara mencari model pembelajaran yang dapat meningkatkan minat siswa dalam memahami konsep-konsep fisika dan menerapkannya dalam kehidupan sehari-hari. Tujuan ini akan tercapai jika model pembelajaran yang digunakan dapat mengaitkan konsep-konsep yang sedang dipelajari dengan situasi dunia nyata dan akan lebih mudah dicapai jika guru memvariasikan model pembelajaran tersebut dengan media pembelajaran yang sesuai. Media pembelajaran yang efektif adalah media pembelajaran yang mampu membantu siswa menvisualisasikan konsep yang sedang dipelajari [6-8]. Salah satu model pembelajaran yang tepat adalah model pembelajaran direct instruction dengan media macromedia flash.

Model pembelajaran Direct Instruction atau disebut juga model pembelajaran langsung merupakan model pembelajaran di mana materi pembelajaran diajarkan dengan pola kegiatan bertahap selangkah demi selangkah [9]. Tidak dapat dipungkiri bahwa untuk bisa memahami konsepkonsep dasar suatu pengetahuan diperlukan instruksi langsung dari seorang guru. Selain itu, melalui model pembelajaran Direct Instruction, guru dapat meminimalisir terjadinya kesalahan konsep (miskonsepsi) karena guru mengarahkan secara langsung materi ajar yang akan disampaikan kepada siswa.

Agar kegiatan pembelajaran menjadi lebih menarik maka penyajian materi pembelajaran dilakukan dengan bantuan media berupa simulasi berbasis macromedia flash. Selain membuat penyajian materi lebih menarik, penggunaan media macromedia flash dilakukan guna membantu siswa dalam memvisualisasikan konsep yang sedang dipelajari sehingga siswa lebih dalam membangun konsep fisika. Media macromedia flash juga memungkinkan guru untuk menyelenggarakan kegiatan pembelajaran yang dengan metode eksperimen. Kegiatan praktikum dapat dilakukan dengan simulasi virtual yang dapat dibuat dengan program macromedia flash. Jadi, selain dapat menyajikan pembelajaran secara langsung, media macromedia flash juga dapat digunakan sebagai media praktikum melalui simulasi virtual sehingga dapat diterapkan tidak hanya pada satu model pembelajaran saja.

Penggunaan model pembelajaran direct instruction sudah banyak diteliti, diantaranya penelitian yang dilakukan oleh Wahyudi etal. [10] yang menyimpulkan bahwa penerapan model pembelajaran Direct Instruction dapat meningkatkan hasil belajar fisika siswa kelas X MAN Ketapang, Kalimantan Barat. Sementara Baramuli etal. [11] menyimpulkan bahwa penerapan model pembelajaran Direct Instruction (DI) dapat meningkatkan hasil belajar IPA siswa kelas VIIA SMPN 12 Pontianak.

Penelitian mengenai penggunaan media macromedia flash sebagai alat bantu ajar juga sudah sering dilakukan yang menyatakan bahwa penggunaan media macromedia flash dapat meningkatkan minat belajar fisika siswa SMAN 1 Tapa yang menyimpulkan bahwa penggunaan media pembelajaran berbasis macromedia flash dapat mengingkatkan motivasi belajar siswa kelas X TKJ 2 SMK Batik Perbaik. Selain itu, penelitian yang mengkombinasikan antara model pembelajaran direct instruction dengan media macromedia flash telah dilakukan oleh Sakti et al. [12] yang menyatakan bahwa model pembelajaran langsung (Direct Instruction) melalui media animasi berbasis macromedia flash berpengaruh terhadap minat belajar dan pemahaman konsep fisika siswa SMA Plus Negeri Kota Bengkulu

Model pembelajaran direct instruction atau pengajaran langsung merupakan model pembelajaran di mana seorang guru menyampaikan informasi secara langsung kepada peserta didik dengan memperhatikan tahapan-tahapan yang ada. Sebagaimana yang telah dijelaskan oleh Jamil mengenai penggunaan pengajaran langsung yaitu untuk menyampaikan pelajaran yang ditransformasikan langsung oleh guru kepada siswa [13].

Direct instruction membutuhkan perencanaan dan pelaksanaan yang sangat hati-hati dipihak guru. Hal ini sesuai dengan pendapat Jupri [14-16] yaitu model direct instruction memerlukan pengelolaan guru dengan cermat, dalam hal alokasi waktu, kejelasan dalam memberikan pengetahuan atau keterampilan baru harus disajikan tahap demi tahap. Agar efektif, pembelajaran langsung mensyaratkan tiap detail keterampilan atau isi didefinisikan secara seksama dan demonstrasi serta jadwal pelatihan direncanakan dan dilaksanakan secara seksama. Metode yang dapat membantu siswa untuk mencari tujuan tersebut adalah variasi antara metode ceramah dan demonstrasi yang dikemas dalam model pembelajaran langsung [17]. Metode ceramah dapat membantu siswa untuk lebih memahami suatu konsep dan informasi dan penjelasan guru dan metode demonstrasi dapat membantu siswa untuk melakukan proses penemuan, mengolah pikiran, dan keterampilan siswa. Hal ini akan mampu membuat proses pembelajaran menjadi lebih efektif dan memberikan pengaruh positif terhadap hasil belajar siswa. 
Pada akhirnya dengan diterapkannya model pembelajaran direct instruction dengan media macromedia flash diharapkan dapat menggantikan model pembelajaran konvensional yang sering diterapkan selama ini. Penggunaan model pembelajaran yang divariasikan dengan media belajar diharapkan dapat menumbuhkan minat dan motivasi belajar siswa sehingga hasil belajar fisika siswa meningkat.

\section{METODE PENELITIAN}

Jenis penelitian ini adalah penelitian eksperimen yaitu penelitian yang digunakan untuk mencari pengaruh perlakuan tertentu terhadap yang lain dalam kondisi yang terkendalikan [13]. Lebih lanjut Setyosari [14] menjelaskan bahwa penelitian eksperimen adalah peneliti memberikan perlakuan kepada subjek atau sekelompok subjek untuk menentukan apakah perlakuan tersebut memiliki dampak atau pengaruh pada variabel tertentu. Desain penelitian yang digunakan yaitu posttest only control group design dimana kelompok eksperimen diberikan perlakuan berupa kegiatan pembelajaran menggunakan model pembelajaran direct instruction dengan media macromedia flash sedangkan kelas kontrol menggunakan pembelajaran konvensional. Kedua kelompok kemudian diberikan tes akhir untuk melihat pengaruh perlakuan yang diberikan.

Penelitian ini dilaksanakan mulai bulan Juli 2016 sampai bulan Januari 2017. Populasi dalam penelitian ini adalah seluruh siswa kelas XI IPA di SMA Negeri 1 Kopang dengan jumlah siswa 83 orang yang terdiri dari 3 kelas. Sampel dalam penelitian yang digunakan yaitu kelas XI IPA 2sebagai kelas ekperimen dan kelas XI IPA 1 sebagai kelas kontrol. Teknik pengambilan sampel dalam penelitian ini yaitu dengan teknik cluster random sampling.

Instrumen yang digunakan dalam penelitian ini adalah tes pilihan ganda (multiple choice) yang sudah diuji validitas, realibilitas, daya beda dan taraf kesukarannya. Berdasarkan hasil uji coba 30 soal, sebanyak 20soal yang sesuai kriteria dan digunakan sebagai soal tes akhir.Data hasil belajar kedua kelas dianalisis menggunakan statistik parametris yaitu $t$ test polled varians,yang sebelumnya sudah diuji normalitas data menggunakan uji chi kuadrat dan uji homogenitas sampel menggunakan uji-F.

\section{HASIL DAN PEMBAHASAN}

Penelitian ini bertujuan untuk mengetahui pengaruh penerapan model pembelajaran direct instruction dengan media macromedia flash terhadap hasil belajar fisika siswa kelas XI SMAN 1 Kopang tahun ajaran 2016/2017. Terdapat dua kelas yang digunakan sebagai sampel yakni kelas XI IPA
2 sebagai kelas ekperimen dan kelas XI IPA 1 sebagai kelas kontrol. Kelas eksperimen diberikan perlakukan dengan menerapkan model pembelajaran direct instruction dengan media macromedia flash sedangkan kelas kontrol menggunakan pembelajaran konvensional yang biasa diterapkan di sekolah.

Analisis data penelitian menunjukkan bahwa hasil tes akhir kelas eksperimen lebih tinggi dibandingkan dengan kelas kontrol. Kelas eksperimen memperoleh nilai rata-rata sebesar 70,71 sedangkan rata-rata kelas kontrol sebesar 62,04. Tabel 2 hasil belajar dan Gambar 1 hasil belajar fisika kedua kelas sampel. Adapun perbandingan rata-rata persentase perolehan skor setiap sub materi antara kelas eksperimen dengan kelas kontrol dapat dilihat pada Tabel 3 dan Gambar 2.

Tabel 2 Analisis Hasil Belajar Fisika Siswa

\begin{tabular}{|l|c|c|}
\hline \multirow{2}{*}{ Komponen } & \multicolumn{2}{|l|}{ Kelas } \\
\cline { 2 - 3 } & Eksperimen & Kontrol \\
\hline Jumlah siswa & 28 & 27 \\
\hline Nilai tertinggi & 85 & 85 \\
\hline Nilai terendah & 35 & 35 \\
\hline Rata-rata & 70,71 & 62,04 \\
\hline Standar Deviasi & 14,25 & 13,32 \\
\hline Varians & 203,17 & 177,42 \\
\hline Uji homogenitas & \multicolumn{2}{|c|}{ Homogen } \\
\hline Uji Normalitas & Normal & Normal \\
\hline Uji Hipotesis & $t_{\text {hitung }}>t_{\text {tabel }}, \mathrm{H}_{0}$ ditolak \\
dan $\mathrm{H}_{\mathrm{a}}$ diterima \\
\hline
\end{tabular}

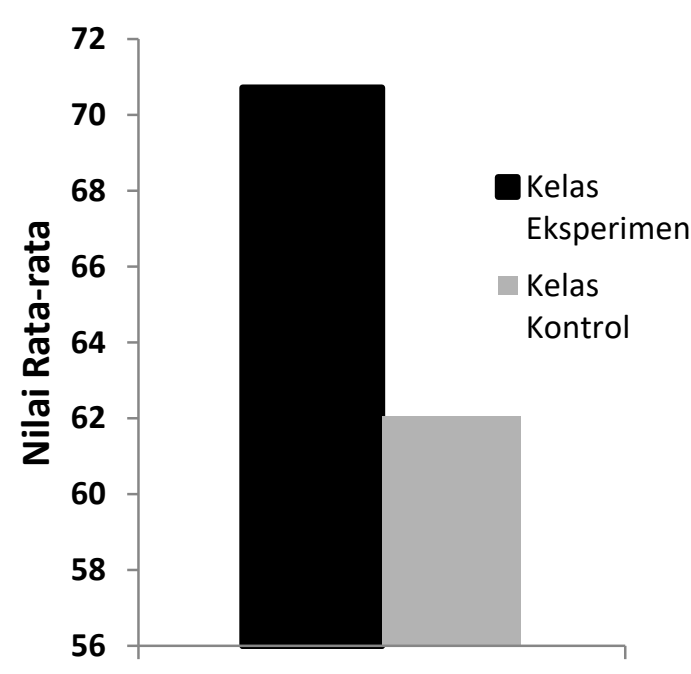

Tes Akhir

Gambar 1 Grafik Rata-Rata Hasil Belajar Fisika Siswa 
Tabel 3 Persentase Perolehan Skor Setiap Sub Materi

\begin{tabular}{lcc}
\hline \multicolumn{1}{c}{ Sub materi } & Kelaseksperimen & Kelaskontrol \\
\hline Impuls dan Momentum & $78 \%$ & $66 \%$ \\
HukumKekekalan Momentum & $44 \%$ & $38 \%$ \\
Tumbukan & $72 \%$ & $67 \%$ \\
\hline
\end{tabular}

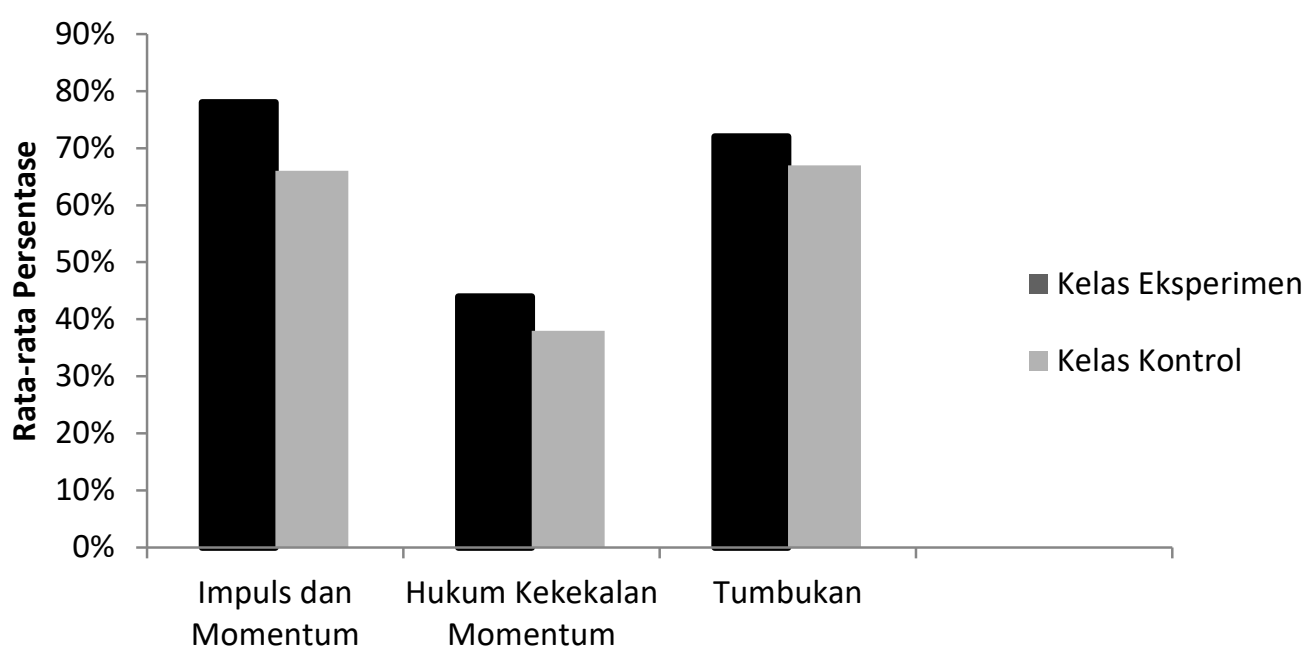

Gambar 2 Rata-rata perolehan skor setiap sub materi

Ada beberapa faktor yang menyebabkan adanya pengaruh pemberian perlakuan terhadap hasil belajar siswa, salah satunya adalah pemberian perlakuan berupa model pembelajaran direct instructiondengan media macromedia flashpada kelas eksperimen, sedangkan pada kelas kontrol menggunakan pembelajaran konvensional dengan metode ceramah. Media yang digunakan disesuaikan dengan kondisi nyata siswa, sehingga dapat mempermudah siswa dalam mempelajari dan memahami materi yang diajarkan.

Selama proses pembelajaran, siswa kelas eksperimen cenderung lebih menikmati pembelajaran yang dipadukan dengan media yang baru mereka lihat. Siswa merasa lebih mudah memahami konsep-konsep yang dipelajari dengan mengamati animasi yang disiapkan sebagai media bantu ajar. Hal ini karena siswa lebih mudah memvisualisasikan konsep yang sedang dipelajari karena dibantu dengan media animasi sehingga konsep tersebut lebih mudah dipahami dan diingat.

Di kelas kontrol yang menggunakan pembelajaran konvensional, guru hanya menjelaskan dan siswa kemudian mencatat apa yang dijelaskan oleh guru. Cara ini ternyata menyebabkan siswa kesulitan untuk memahami konsep yang dipelajari. Kesulitan ini disebabkan kurangnya kemampuan siswa untuk memvisualisasikan konsep-konsep fisika. Kurangnya kemampuan memvisualisasi konsep ini tidak dapat diatasi oleh siswa dengan sendirinya. Siswa membutuhkan alat bantu atau media yang dapat memvisualisasikan konsep yang dipelajari.
Model pembelajaran direct instruction yang diterapkan pada kelas eksperimen memiliki keunggulan dalam mempelajari bahan keterampilan dasar (pengetahuan prosedural) dan memperoleh informasi (pengetahuan deklaratif) yang diajarkan selangkah demi selangkah. Hal ini sesuai dengan pendapat Arends (dalam Sahidu, 2013) dimana model pengajaran langsung adalah salah satu pendekatan mengajar yang dirancang khusus untuk menunjang proses belajar siswa yang berkaitan dengan pengatuhan deklaratif dan pengetahuan prosedural yang terstruktur dengan baik, artinya pengajaran dirancang sangat sistematis sehingga dapat mempermudah siswa dalam memahami materi secara bertahap. Selain itu, siswa juga terlibat aktif dan antusias dalam sistem pembelajaran, karena pada prinsip model pembelajaran direct instruction selalu melibatkan siswa dalam melakukan demonstrasi pengetahuan dan siswa akan diberikan umpan balik untuk mengetes pemahaman siswa terhadap suatu materi yang sudah dipelajari. Selain itu, penggunaan model pembelajaran direct instruction tersebut, juga menggunakan bantuan media yaitu berupa animasi berbasis macromedia flash. Media ini disusun secara sistematis dan teratur serta substansi materinya dikaitkan dengan kehidupan sehari-hari siswa yaitu tentang konsep impuls dan momentum, sehingga dapat mempermudah siswa dalam memahami materi yang diajarkan.

Pembelajaran konvensional dengan metode ceramah yang diterapkan pada kelas kontrol adalah metode belajar yang cara penyajiannya dihadapkan 
hanya kepada suatu masalah yang bisa berupa pernyataan atau pertanyaan yang bersifat problematis untuk dibahas dan dipecahkan bersama atau secara kolektif. Proses pembelajaran di dalamnya siswa hanya mendengar dan mencatat setiap informasi yang disampaikan oleh guru. Hal ini membuat siswa kurang berperan secara aktif dan antusias belajar siswa rendah, sehingga dapat mempengaruhi hasil belajar siswa menjadi rendah pula.

Data hasil tes akhir menunjukkan terdapat perbedaan rata-rata hasil belajar siswa kelas eksperimen dengan kelas kontrol, meskipun hasil tes kedua kelas berada di atas KKM. Pencapaian hasil belajar di atas KKM bukanlah menjadi tolak ukur utama dalam penelitian ini, melainkan data hasil belajar setelah diberikan perlakuan (tes akhir) pada kedua kelas. Pengujian hipotesis dilakukan dengan rumus uji-t. yang merupakan uji beda. Hasil uji hipotesis tes akhir menunjukkan bahwa $t_{\text {hitung }}>$ $t_{\text {tabel }}$ di mana $t_{\text {hitung }}=2,33, t_{\text {tabel }}=2,00$ itu artinya terdapat perbedaan hasil belajar antara kelas yang diberikan perlakuan dengan kelas yang tidak diberikan perlakuan.Berdasarkan kriteria pengujian hipotesis maka $\mathrm{H}_{\mathrm{o}}$ ditolak dan $\mathrm{H}_{\mathrm{a}}$ diterima, artinya bahwa terdapat pengaruh pemberian model pembelajaran direct instructiondengan media macromedia flash terhadap hasil belajar fisika siswa kelas XI SMAN 1 Kopang tahun ajaran 2016/2017.

\section{PENUTUP}

Berdasarkan hasil penelitian dan pembahasan seperti yang telah dipaparkan, maka dapat disimpulkan bahwa model pembelajaran direct instruction dengan media macromedia flash pada materi pokok impuls dan momentum berpengaruh terhadap hasil belajar fisika siswa kelas XI SMAN 1 Kopang tahun ajaran 2016/2017.

\section{DAFTAR PUSTAKA}

[1] Kesipudin, K., \& Hikmawati, H. (2009). Model pembelajaran terpadu untuk sains. Jurnal PIJAR MIPA, 4(2).

[2] Hikmawati, H. (2009). Implementasi modulfisika smpmateri pokok gerak dengan menerapkan model pengajaran langsung dan model pembelajaran kooperatif. Jurnal PIJAR MIPA, 4(1).

[3] Apriani, N., Ayub, S., \& Hikmawati, H. (2016). Pengaruh Model Pembelajaran Berbasis Masalah Terhadap Hasil Belajar Fisika Siswa Kelas X SMAN 2 Praya Tahun Pelajaran 2015/2016. Jurnal PIJAR MIPA, 11(2).
[4] Setiawan, T., Rahayu, S., \& Hikmawati, H. (2015). Pengaruh Model Pembelajaran Science Technology And Society Dengan Metode Diskusi Terhadap Hasil Belajar Fisika Siswa Kelas VIII SMPN 1 Labuapi Tahun Ajaran 2014/2015. Jurnal PIJAR MIPA, 10(2).

[5] Hikmawati, H. (2016). Lembar Kerja Siswa Berbasis Saintifik Pada Konsep Hukum Ohm Untuk Pembelajaran Fisika Di Sekolah Menengah Atas. Jurnal PIJAR MIPA, 11(1).

[6] Taufiq, M. (2008). Pembuatan Media Pembelajaran Berbasis Compact Disc Untuk Menampilkan Sim-ulasi Dan Virtual Labs Besaran-Besaran Fisika. Jurnal Pijar MIPA, 3(3), 68-72.

[7] Gunawan, G., Harjono, A., \& Sutrio, S. (2017). Multimedia Interaktif dalam Pembelajaran Konsep Listrik bagi Calon Guru. Jurnal Pendidikan Fisika dan Teknologi, 1(1), 9-14.

[8] Al-idrus, S. Q. M. J., Hikmawati, H., \& Wahyudi, W. (2015). Pengaruh model pembelajaran berbasis masalah berbantuan video kartun terhadap hasil belajar fisika siswa kelas xi sman 1 sikur tahun ajaran 2014/2015. Jurnal Pijar MIPA, 10(1).

[9] Sahidu, C. 2013. Penilaian Hasil Belajar. Mataram: Arga Puji Press.

[10] Wahyudi. Astriyani, Nurhayati. (2015). Penerapan Model Direct Instruction terhadap Hasil Belajar Fisika Materi Pengukuran Ditinjau dari Gender Pada Siswa Kelas X MAN Ketapang. Jurnal IKIP PGRI Pontianak. Jurnal Pend. Informatika dan Sains, 1.2, 2, 187-200.

[11] Baramuli, Y., Stepanus, S.S, \& Haratua, T.M.S. (2015). Peningkatan Hasil Belajar Fisika Siswa dengan Model Direct Instruction di SMP. Jurnal Fisika FKIP Untan Pontianak, 1, 3

[12] Sakti, I., Puspasari, Y.M., Risdianto, E. (2012). Pengaruh Model Pembelajaran Langsung melalui Media Animasi Berbasis Macromedia Flash terhadap Minat Belajar dan Pemahaman Konsep Fisika Siswa di SMA Plus Negeri 7 Kota Bengkulu.Bengkulu: Jurnal Exacta, X, 1.

[13] Jamil, S. 2013. Strategi Pembelajaran: Teori dan Aplikasi. Yogyakarta: Ar-Ruzz Media. 
[14] Jupri, W. 2010. Belajar dan Pembelajran Sains. Mataram: Arga Puji Press.

[15] Makhrus, M. (2009). Pengembangan Perangkat Strategi Belajar Mapping Melalui Model Direct Instruction. Jurnal PIJAR MIPA, 4(1).

[16] Wenno, H. (2014). Direct Instruction Model to Increase Physical Science Competence of Students as One Form of Classroom Assesment. International Journal of Evaluation and Research in Education, 3(3), 169-174.

[17] Saputro, B. (2016). Pengembangan Model Manajemen Pembelajaran Direct Intruction Berfokus Film Dalam Pengantar Praktikum IPA. Holistik, 1(1). 